\title{
Interpreting Kant's Conception of Proper Science in Practical Realism ${ }^{1}$
}

\author{
Rein Vihalemm \\ Department of Philosophy, \\ Institute of Philosophy and Semiotics, \\ University of Tartu \\ Ülikooli 18 , \\ Tartu 50090, Estonia \\ E-mail: Rein.Vihalemm@ut.ee
}

\begin{abstract}
Immanuel Kant can be regarded as a philosopher related to the Baltic region. This paper, however, is not a historical study of the Baltic reception of Kant's philosophy, but of Kant's concept of proper science (eigentliche Wissenschaft), which is analyzed by comparing it to a theoretical model of science- $\varphi$-science-developed within the context of practical realism. The issues of realism and practice in philosophy of science-as well as their relations to Kant's philosophical legacy —have been centrally important in the Baltic-Nordic region. According to Kant, only quantified sciences, exemplified by physics, are proper sciences, because mathematics provides a priori principles for cognizing physical laws, thus affording apodictically certain knowledge. This conception is rooted in transcendental idealism. In this paper it is shown how Kant's transcendental idealism and apriorism as the basis for properly scientific_apodictically certain_-knowledge can be overcome (or rather, "sublated") within the practical realist position.
\end{abstract}

Keywords: apodictically certain knowledge, $\varphi$-science, Heidegger, Kant, Marx, practical realism, proper science, transcendental idealism

\footnotetext{
The first version of this paper was read at the XXV International Baltic Conference on the History of Science (Vilnius, October 4-6, 2012). I would like to thank the participants of the philosophy session of that conference for discussion, including the lobby conversations later. I would also like to mention that this article has remained more or less within that short presentation. I have developed the topic in more detail in another article in the context of philosophy of chemistry (Vihalemm, in press, a).
} 


\section{Introduction}

Immanuel Kant can be regarded as a philosopher who is related to the Baltic context. This can be said not only because Kant was a lifelong resident of Königsberg (present-day Kaliningrad) and a professor at the local university, now called the Immanuel Kant Baltic Federal University in Kaliningrad, and because his main works were published in Riga, but also because in the early $19^{\text {th }}$ century Kant's philosophy was dominant at the University of Tartu. One of Kant's pupils and Privatdozent in Königsberg, Gottlob Benjamin Jäsche, who is principally known within history of philosophy as the publisher of Kant's Logic in Köningsberg (Jäsche, 1800), served as a professor at the University of Tartu from 1802 to 1839 . This article, however, is not a historical study of the reception of the philosophy of Kant in Estonia, nor in the other Baltic or Nordic countries. Instead I shall discuss current philosophical problems.

At the previous Baltic Conference I presented a paper on practical realism in philosophy of science (Vihalemm, 2011a). The issues of realism and practice in philosophy of science-as well as their relation to Kant's philosophical legacyhave been centrally important within the Baltic-Nordic region. In this respect, for instance, the special issue of Studia Philosophica Estonica, containing the proceedings of the international workshop on practical realism in Tartu (summer of 2011), which included discussions of Kant's views (see, e.g., Pihlström, 2012; Vihalemm, 2012) is also worth mentioning.

Looking back about 50 years, it cannot escape notice that the historical background for the development of philosophy of science in Estonia (as in other Baltic countries) and in Finland (as in other Nordic countries) is quite different-representing one variety or another of Marxist philosophy in the former, and primarily the analytic tradition in the latter. What actually counts as Marxist philosophy in the Soviet era here, especially within philosophy of science, is of course a distinct issue, which I have considered previously, also at the Baltic conferences (Vihalemm, 2006; 2008; in press, b). Here I wish to emphasize that the problem of realism and the "turn to practice" in philosophy of science associated with Thomas Kuhn's work can be understood, readily and quite naturally, within practical realism, which originates, I think, in Karl Marx's "Theses on Feuerbach" (1845), when interpreted in the context of contemporary philosophy.

Relevant here is also Sami Pihlström's view in the indicated volume of Tartu workshop papers. Pihlström suggests that a contemporary scientific realist should 
be prepared to accept the pragmatically naturalized Kantian transcendental perspective on realism (Pihlström, 2012). However, this naturalization of Kantian transcendentalism leaves his transcendental idealism in force. On my reading, a realistically naturalized Kantianism can only be practical realism. In this connection it deserves noting that we now have an excellent book (Westphal, 2004) which develops a positive reinterpretation of Kant's 'critical philosophy' as an unrestricted realism, including, as the author puts it, "a genuinely transcendental proof of realism sans phrase" (Westphal, 2004, p. 35), so that "transcendental idealism is not, pace Kant, required for" the critical tasks of his philosophy; moreover, "Kant's transcendental idealism is unsupported, false, nor can it fulfill some of the key aims Kant claims it alone can fulfill..." (Westphal, 2004 , p. 34). Kenneth Westphal confirmed to me in personal communication that his realism sans phrase cannot be interpreted as metaphysical realism, and it agrees entirely with practical realism (and with pragmatic realism as well, in this point) that there is no "pre-made world"; our ontology of nature can only result from scientific inquiry, which is a host of practices of inquiry.

Within the context of practical realism I have developed a concept of $\varphi$-science (see, e.g., Vihalemm, 2007). Here I use this concept to analyze briefly Kant's concept of proper science (cf. Plaass, 1994; van den Berg, 2011).

\section{Kant's proper science and a theoretical model of science- $\varphi$ - science}

Kant's well-known dictum is:

I assert [...] that in any special doctrine of nature there can be only as much proper science [eigentliche Wissenschaft] as there is mathematics therein. For, according to the foregoing, proper science, and above all proper natural science, requires a pure part lying at the basis of the empirical part, and resting on a priori cognition of natural things. (Kant, 2002b[1786], 4, p. 470) ${ }^{2}$

According to Kant, mathematics provides a priori principles for cognizing physical laws, thus affording apodictically certain knowledge of them. I contend instead that Kant's transcendental idealism and apriorism as premises of proper scientific_apodictically certain—knowledge can be overcome (or rather, "sublated") within the practical realist position. I say "sublated", bearing in

\footnotetext{
2 Citations are given, as usual, with volume and page numbers of Kants Gesammelte Schriften.
} 
mind Hegel's term aufheben (translated into English as 'sublate', Aufhebung as 'sublation'; in Estonian 'ületamine'), which has this familiar threefold meaning: "to cancel", "to preserve" and "to elevate".

My concept of $\varphi$-science, developed in the context of practical realism, is quite similar to Kant's proper science, provided the latter is interpreted also practicalrealistically. I have introduced $\varphi$-science as a theoretical model of an idealized science. This model is a theoretical concept of science ${ }^{3}$ developed on the basis of physics, which I have used to analyze chemistry comparatively. This is a model of an exact science, whether in fact or in principle. The foundation of $\varphi$-science is the mathematical projection operating with experimentally substantiated idealizations, and used to examine the world to identify laws of nature. Speaking about natural science in general (in an unspecified sense of this term), two main types of cognition can be differentiated: (i) $\varphi$-scientific cognition, which has a constructive-hypothetico-deductive character, and (ii) non- $\varphi$-scientific (or natural historical) cognition, which has a classificatory-historico-descriptive character (such as, say, geology or classical biology). ${ }^{4}$ This non- $\varphi$-scientific, classificatory-historico-descriptive type of cognition and knowledge can be construed in a broader and a narrower sense. Here it is meant in a narrower sense, as natural history. In a broader sense it includes also social studies and the humanities. It is reasonable, however, at least in some cases, to highlight the difference of the social-humanitarian studies from science in general (i.e. not only from $\varphi$-science), although they are not to be classified as studies of an "inferior type" (for details see Vihalemm, 2011b, pp. 86-92).

Physics has obtained the status of the standard of science. The question is why? What gives to physics, to its laws and theories the status of being the very paragon of scientific as such? It is obvious that physics is not regarded as science simply because it is physics, and physical laws and theories are not regarded as scientific simply because they are physical. It is unhelpful to say that physical theories are scientific because they are mathematically formulated. It is also necessary to understand philosophically what exactly this mathematical formulation is, and why it has been most successful only in physics. All these questions are

3 In my view, the reference of a scientific concept should be seen in the following way (see Vihalemm, 2013): It is a certain abstract object - in the case of theoretical concept, an idealized construction — that is a model of a certain actual system given through practice. The meaning (sense) of the concept lies in the referring activity, in the procedures by which the reference is found and the relevant abstract object constructed. It involves the understanding of the role of certain real objects and phenomena, their relations, functions, characteristics, the ways they are handled in a certain system of human activity, i.e. in scientific practice. The concept is like a scheme for constructing, creating or recreating something.

4 Actually, the full scheme is more complicated, see Fig. 1, p. 86 in Vihalemm, 2011b. 
discussed by Kant as well. An excellent analysis of these questions is also made in twentieth-century continental philosophy by Martin Heidegger (see especially Heidegger, 2011a[1962]), whose ideas, unfortunately, have until quite recently been ignored in philosophy of science. In my opinion, however, and perhaps surprisingly, Heidegger's historical approach is also compatible with practical realism.

\section{Kant's "Copernican revolution" and practical realism}

According to practical realism, to speak about the world outside practice means to speak about something indefinable or illusory: only through practice can the objective world exist (as something specific and definite) for human beings. Therefore, knowledge must be regarded as the process of understanding how the world becomes defined in and through practice. One should say that science as practice is a way we engage with the world and that allows the world to show how it can be identified in its own possible "versions". We are not "world makers". The world, however, does not consist of self-identifying objects; objects are identifiable-in principle, in a potentially infinite number of ways (in this sense they are inexhaustible, having innumerable aspects and connections with the rest of the world) - through practice. And practice is, in short, human activity as a socio-historical, critically purposeful-normative, constructive, material interference with nature and society producing and reproducing the human world—culture—in nature.

Today's philosophy of science cannot ignore the Kantian "Copernican revolution" concerning experience and apodictic knowledge in general: when, instead of assuming that "all our knowledge of objects must conform to objects", we "suppose that objects must conform to our knowledge", it will "be possible to have knowledge of objects a priori, determining something in regard to them prior to their being given" (Kant, 1929[1787], B xvi). Kant elaborated this idea further especially regarding the issue of how science as apodictic knowledge of nature is possible (Plaass, 1994; van den Berg, 2011). The question is, however, as mentioned, how to overcome his transcendental idealism. I would like to emphasize that this was already shown by Marx. In his "Theses on Feuerbach", Marx argued (in the first thesis) against previous materialism and idealism in philosophy, that the world, "the thing [Gegenstand], reality, sensuousness," was conceived in pre-Marxist materialism 
only in the form of the object [Objekt] or of intuition [Anschauung], but not as human sensuous activity, practice, not subjectively. Hence it happened that the active side, in contradistinction to materialism, was developed by idealism - but only abstractly, since, of course, idealism does not know real, sensuous activity as such. (Marx, 1845)

In the second thesis Marx emphasized: "The dispute over the reality or nonreality of thinking in isolation from practice is a purely scholastic question" (Marx, 1845). And in the Economic and Philosophic Manuscripts of 1844 (in his Critique of Hegel's Philosophy in General), he wrote: "nature [...], taken abstractly, for itself-nature fixed in isolation from man-is nothing for man" (Marx, 1844).

\section{Rediscovering Marx through ... Heidegger}

The recent considerations of Heidegger's realism (e.g., Kochan, 2011; Glazebrook, 2001 ; 2012) are also relevant here. Kochan's reading of Heidegger proves to accord with my practical realism. Kochan contends that Heidegger's "Being-inthe-World" can be interpreted as "Practice":

On Heidegger's account [...] the root problem of both realism and antirealism is that they both begin their analysis one level too late. They start at the level of subject and object rather than at the more primitive level of Dasein [Being-in-the-World] and world. Insofar as both realists and antirealists rely upon a theoretical conception of the world as reality [viz., an ontology of objecthood (Kochan, 2011, p. 95)—Author's note], they both fail to get at the real in a way which discloses entities in their more fundamental, nonobjectival state. (Kochan, 2011, p. 89)

Similarly, Glazebrook argues that Heidegger can be regarded as a robust scientific realist, albeit one "who nonetheless holds anti-realist" - as distinct from idealist—-assumptions", insofar as human understanding is projective, so that the idea of reality independent of understanding is unintelligible. Glazebrook shows that "this position is neither garbled nor self-contradictory" (Glazebrook, 2001, p. 362).

Heidegger's realism is understandable on the basis of his idea of the ontological difference, that is the difference between being and beings: the being of beings (entities) is not itself yet another being among them; instead it is the possibility 
of their intelligibility. "Heidegger is a realist about beings, but an antirealist about being" (Glazebrook, 2001, p. 362).

I would like to summarize this short analysis of Kant's philosophy of science as follows. We know that Kant "freely admitted" in his Prolegomena to Any Future Metaphysics that David Hume "first interrupted [his] dogmatic slumber, and gave a completely different direction to [his] researches in the field of speculative philosophy" (Kant, 2002[1783], 4, p. 260)5. This was Kant's famous "Copernican revolution", based on his apriorism and transcendental idealism. I would like to say, however, that appreciating these Kantian revolutionary views, we need, though, to be interrupted perhaps now from this slumber of speculative philosophy at all. As Kenneth Westphal has shown, Kant fails to provide a metaphysical foundation - "rooted in [...] transcendental idealism" (Westphal, 2004, p. 175)—for physics. And I think that the role analogical to what Hume played for Kant, in this overcoming or sublation of Kantianism could, in its turn, be played by Marx-especially his "Theses on Feuerbach". But maybe, paradoxically, philosophy of science will reach practical realism and notice and recognize Marx, through Heidegger. Heidegger agrees with Kant in that whatever one must presuppose in order to know any object whatsoever, cannot itself be known as an object (Objekt; A 402), but disagrees with Kant that these presuppositions must be transcendentally ideal; instead, Heidegger contends, they are ways of being in the world, that is, ways we behave, act and find ourselves within our surroundings. ${ }^{6}$

I would like to draw attention to the fact Heidegger wrote in his last essay "The End of Philosophy and the Task of Thinking" (1964), where he explains that the end of philosophy means its evolving into the sciences as gathering the whole of philosophy's history in its uttermost possibility, although a task remains for thinking, "a task accessible neither to philosophy as metaphysics nor, even less, to the sciences stemming from philosophy" (Heidegger, 2011b[1964], p. 314). Occidental philosophy, Heidegger contends, both needs and considers it possible that there is a highest, somehow privileged entity, a God-like ground or cause as a trustworthy principle or key to construe beings as a whole, comprehensible to human understanding; this aspiration Heidegger characterizes as 'onto-theology'. With these issues, and this designation in mind, Heidegger writes:

Philosophy is metaphysics. Metaphysics thinks beings as a whole... (p. 312) [...] [S]ince Aristotle it has become the task of philosophy as metaphysics

Citations are given, as usual, with volume and page numbers of Kants Gesammelte Schriften.

I owe this comparison of Kant's and Heidegger's views to Kenneth Westphal. 
to think beings as such ontotheologically (p. 322). [...] Metaphysics is Platonism (p. 313). [...] [W] hat we say about the end of philosophy means the completion [attaining the uttermost possibility-Author's note] of metaphysics (p. 312). [...] With the reversal of metaphysics that was already accomplished by Karl Marx, the uttermost possibility of philosophy is attained (p. 313).

Metaphysics is exhausted, but practical realist thinking remains, to be appreciated and furthered.

\section{References}

Glazebrook, T. (2001), 'Heidegger and scientific realism,' Continental Philosophy Review, vol. 34, pp. 361-401. http://dx.doi.org/10.1023/A:1013148922905

—, ed. (2012), Heidegger on Science, New York: State University of New York Press.

Heidegger, M. (2011a[1962]), 'Modern Science, Metaphysics, and Mathematics,' in D. F. Krell (ed.) Martin Heidegger: Basic Writings from Being and Time (1927) to Task of Thinking (1964). With a foreword by Taylor Carman. London \& New York: Routledge Classics, pp. 183-212 [Original: Heidegger, M. (1962), Die Frage nach dem Ding, Tübingen: Max Niemeyer Verlag, pp. 50-83].

(2011b[1964]), 'The End of Philosophy and the Task of Thinking,' in D. F. Krell (ed.) Martin Heidegger: Basic Writings from Being and Time (1927) to Task of Thinking (1964). With a foreword by Taylor Carman. London \& New York: Routledge Classics, pp. 311-325 [Original: Heidegger, M. (1964), 'Das Ende der Philosophie und die Aufgabe des Denkens,' Essay written for the UNESCO colloquium "Kierkegaard vivant", Paris, April 21-23].

Jäsche, G. B. (1800), Kants Logik, ein Handbuch zu Vorlesungen, herausgegeben von Gottlieb Benjamin Jäsche, Köningsberg: bey Freiderich Nicolovius.

(1816), Einleitung zu einer Architektonik der Wissenschaften nebst einer Skiagraphie und allgemeinen Tafel des gesammten Systems menschlicher Wissenschaften nach architektonischem Plane / zunächst zum Gebrauche für seine encyklopädischen Vorlesungen von Gottlob Benj. Jäsche, Professor der Philosophie zu Dorpat, Dorpat: J. C. Schünmann.

Kant, I. (1929[1787]), Kant's Critique of Pure Reason, transl. by N. K. Smith, London: MacMillan [Original: Kritik der reinen Vernunft (Zweite hin und wieder werbesserte Auflage), cited as 'B' for its $2^{\text {nd }}$ edition, and 'A' for the $1^{\text {st }}$ edition].

- (2002a[1783]), Prolegomena to Any Future Metaphysics that will be able to come forward as Science, transl. by G. Hatfield, H. Allison \& P. Heath, in P. Guyer \& 
A. Wood (eds.) Theoretical Philosophy after 1781. The Cambridge Edition of the Works of Immanuel Kant in Translation, Cambridge: Cambridge University Press http://dx.doi.org/10.1017/CBO9780511498015.003

[Original: Kant, I. (1783), Prolegomena zu einer jeden künftigen Metaphysik, die als Wissenschaft wird auftreten können]. Citations are given, as usual, with volume and page numbers of Kants Gesammelte Schriften.

(2002b[1786]), Metaphysical Foundations of Natural Science, transl. by M. Friedman, H. Allison \& P. Heath, in P. Guyer \& A. Wood (eds.) Theoretical Philosophy after 1781. The Cambridge Edition of the Works of Immanuel Kant in Translation, Cambridge: Cambridge University Press http://dx.doi.org/10.1017/CBO9780511498015.004

[Original: Kant, I. (1786), Metaphysische Anfangsgründe der Naturwissenschaft]. Citations are given, as usual, with volume and page numbers of Kants Gesammelte Schriften.

Kochan, J. (2011), 'Getting Real with Rouse and Heidegger,' Perspectives on Science, vol. 19, no. 1, pp. 81-115.

http://dx.doi.org/10.1162/POSC_a_00026

Marx, K. (1844), Economic and Philosophic Manuscripts of 1844 [Original: Ökonomischphilosophischen Manuskripte aus dem Jahre 1844], retrieved from http://www. marxists.org/archive/marx/works/1844/manuscripts/hegel.htm [accessed August 2013]

(1845), 'Theses on Feuerbach' [Original: Thesen über Feuerbach], retrieved from http://chss.montclair.edu/English/furr/gned/marxtonf45.pdf [accessed August 2013]

Pihlström, S. (2012), 'Toward Pragmatically Naturalized Transcendental Philosophy of Scientific Inquiry and Pragmatic Scientific Realism,' Studia Philosophica Estonica, vol. 5, no. 2, pp. 79-94.

Plaass, P. (1994), Kant's Theory of Natural Science, Translation, Analytic Introduction and Commentary by Alfred E. and Maria G. Miller. With an Introductory Essay by Carl Friedrich von Weizsäcker, Dordrecht et al:: Kluwer Academic Publishers.

van den Berg, H. (2011), “Kant's conception of proper science," Synthese, vol. 183, pp.7-26. http://dx.doi.org/10.1007/s11229-009-9665-y

Vihalemm, R. (2006), 'On the Conception of the Practical Nature of Science: Reflecting on the Development of Philosophy of Science in Estonia,' in Historia Scientarum Baltica, Abstracts of XXII Baltic Conference on the History of Science in Vilnius, October 5-6, 2006, pp. 116-117.

(2007), 'Philosophy of chemistry and the image of science,' Foundations of Science, vol. 12, no. 3, pp. 223-234.

http://dx.doi.org/10.1007/s10699-006-9105-0

(2008), 'Theoretical Philosophy and Philosophy of Science in the Soviet Times:

Some Remarks on the Example of Estonia in 1960-1990,' in Nova Miscellanea 
Historiae Scientarum Baltica - 50. Abstracts and Programme of the $23^{\text {rd }}$ International Baltic Conference on the History of Science, Riga, 9-10 October, 2008. Riga: RTU Publishing House, pp. 23-24.

(2011a), 'Towards a Practical Realist Philosophy of Science,' Baltic Journal of European Studies, vol. 1, no. 1(9), pp. 46-60. Available also online at http://www. ies.ee/iesp/No9/articles/05_Vihalemm.pdf [accessed August 2013]

(2011b), 'A Monistic or a Pluralistic View of Science: Why Bother?' in P. StekelerWeithofer, H. Kaden, \& N. Psarros (eds.) An den Grenzen der Wissenschaft: Die "Annalen der Naturphilosophie" und das natur- und kulturphilosophische Programm ihrer Herausgeber Wilhelm Ostwald und Rudolf Goldscheid. Die Vorträge der Konferenz, veranstaltet von der Sächsischen Akademie der Wissenschaften zu Leipzig und dem Institut für Philosophie der Universität Leipzig im November 2008 (Abhandlungen der Sächsischen Akademie der Wissenschaften zu Leipzig. Philologisch-historische Klasse. Band 82, Heft 1: 79-93). Stuttgart/Leipzig: Sächsische Akademie der Wissenschaften zu Leipzig; In Kommission bei S. Hirzel.

(2012), 'Practical Realism: Against Standard Scientific Realism and Anti-Realism,' Studia Philosophica Estonica, vol. 5, no. 2, pp. 7-22. Available also online at http:// www.spe.ut.ee/ojs-2.2.2/index.php/spe/article/view/149/70 [accessed August 2013] (2013), 'What is a Scientific Concept? Some Considerations Concerning Chemistry in Practical Realist Philosophy of Science,' in J.-P. Llored (ed.) The Philosophy of Chemistry: Practices, Methodologies and Concepts, Cambridge: Cambridge Scholars Publishing, pp. 364-384.

(in press, a), 'Science, $\varphi$-Science, and the Dual Character of Chemistry,' in G. Fisher \& E. Scerri (eds.) Chapter in Philosophy of Chemistry, New York: Oxford University Press.

(in press, b), 'Theoretical Philosophy and Philosophy of Science in the Soviet Times: Some Remarks on the Example of Estonia, 1960-1990,' Studia Philosophica Estonica. Published as Online First, retrieved from http://www.spe.ut.ee/ojs-2.2.2/ index.php/spe/article/viewFile/77/81 [accessed August 2013]

Westphal, K. R. (2004), Kant's Transcendental Proof of Realism, Cambridge: Cambridge University Press.

http://dx.doi.org/10.1017/CBO9780511584497

Rein Vihalemm is currently professor emeritus and part-time Professor of Philosophy of Science at the Department of Philosophy, University of Tartu, Estonia. He received his $\mathrm{PhD}$ in Philosophy from the Institute of Philosophy of the Academy of Sciences of the former USSR (Moscow, 1969) and a Diploma (MSc) in Chemistry from the University of Tartu, Estonia (1963). 